\title{
Media Pembelajaran Berbentuk Kartu dengan Metode Permainan UNO pada Materi Protista
}

\section{Rahmi Aulya ${ }^{\text {* }}$, Zulyusri2 ${ }^{2}$ Rahmawati ${ }^{3}$}

1,2,3 Universitas Negeri Padang, Padang, Indonesia

\section{A R T I C L E I N F O}

Article history:

Received May 26, 2021

Revised May 27, 2021

Accepted August 20, 2021

Available online October 25, 2021

Kata Kunci:

Kartu UNO, Metode Permainan, Protista, Biologi

Keywords:

UNO Card, Game Method,

Protista, Biology

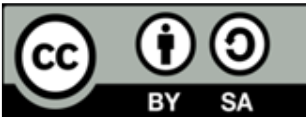

This is an open access article under the CC BY-SA license.

Copyright ( $(2) 2021$ by Author. Published by Universitas Pendidikan Ganesha.

\begin{abstract}
A B S T R A K
Saat proses pembelajaran biologi pada materi protista guru telah menggunakan media berupa power point serta video dan untuk pemantapan materi guru menggunakan LKPD yang sudah dirancang. Namun kelemahan dari media pembelajaran yang digunakan tersebut masih belum bisa menarik perhatian peserta didik dalam mempelajari materi Protista. Penelitian ini bertujuan untuk menganalisa kebutuhan pengembangan media pembelajaran berbentuk kartu dengan metode permainan UNO pada materi protista. Studi dilakukan dengan metode survei. Sampel penelitian yaitu 30 peserta didik yang dipilih secara acak pada 5 kelas yang berbeda dan satu orang guru biologi Instrumen yang digunakan dalam penelitian ini yaitu angket. Pengumpulan data dilakukan dengan menyebarkan angket kepada peserta didik dan guru biologi melalui google formulir. Teknik analisis data yang digunakan adalah teknik analisis data statistik deskriptif kuantitatif. Hasil analisis menunjukkan bahwa peserta didik membutuhkan media pembelajaran tambahan pada materi protista, kriteria media pembelajaran yang dibutuhkan oleh peserta didik yaitu materi yang disampaikan lengkap, singkat, padat dan disertai gambar dan menggunakan metode permainan. Pengembangan media pembelajaran berbentuk kartu dengan metode permainan UNO dapat menjadi solusi dari permasalahan yang dihadapi oleh guru dan peserta didik khusunya pada materi protista.
\end{abstract}

\section{A B S T R A C T}

While learning biology on protist material, the teacher has used media in the form of power points and videos, and for strengthening the material, the teacher uses the LKPD that has been designed. However, the weakness of the learning media used is still unable to attract students' attention in studying Protista material. This study aims to analyze the need for developing learning media in the form of cards with the UNO game method on protist material. The study was conducted by survey method. The research sample was 30 students randomly selected in 5 different classes and one biology teacher. The instrument used in this study was a questionnaire. Data was collected by distributing questionnaires to students and biology teachers via google forms. The data analysis technique used is the descriptive quantitative statistical data analysis technique. The analysis results show that students need different learning media on protist material. The criteria for learning media needed by students are complete, short, dense and accompanied by pictures and using game methods. The development of learning media in the form of cards with the UNO game method can solve the problems faced by teachers and students, especially in protist material.

\section{PENDAHULUAN}

Kualitas pendidikan sangat penting untuk kelangsungan hidup bangsa dan Negara. Pendidikan berperan penting dalam membentuk manusia menjadi pribadi yang lebih baik (Amini \& Suyadi, 2020; Mardliyah et al., 2021). Dalam mencapai tujuan pendidkan harus dimulai dengan menciptakan pembelajaran yang berkualitas. Dalam proses pembelajaran guru memegang peranan yang sangat penting untuk meningkatkan kualitas Pendidikan (S. Liu et al., 2021; Y. Liu et al., 2020). Guru harus mampu menciptakan suasana belajar yang menyenangkan melalui pembelajaran yang efektif dengan memilih 
metode dan model pembelajaran yang sesuai dengan karakteristik siswa (Febriana, 2017; Nisa \& Sujarwo, 2020; Rediasih et al., 2019). Selain itu tugas guru harus mampu bertanggung jawab serta melakukan inovasi-inovasi dengan menerapkan strategi pembelajaran yang baik (Range et al., 2013; Wahyono et al., 2020). Pembelajaran akan lebih menarik untuk siswa apabila guru menggunakan alat bantu berupa media pembelajaran. Pemanfaatan media pembelajaran yang relevan didalam kelas dapat mengoptimalkan proses pembelajaran dan membuat siswa menjadi lebih aktif dan mencapai tujuan pembelajaran (Khaulani et al., 2019; Ulfah \& Soenarto, 2017). Siswa tidak mengalami kejenuhan ataupun kebosanan saat pembelajaran berlangsung ketika menggunakan media pembelajaran (Karo \& Rohani, 2018; A. Rahmawati, 2018). Penggunaan media pembelajaran dapat meningkatkan perhatian serta keaktifan peserta didik terhadap topik yang dipelajari (Buchori et al., 2017; H. Handayani et al., 2018; Sadikin \& Hakim, 2019). Bantuan media pembelajaran akan meningkatkan gairah belajar dan motivasi peserta didik sehingga pada hasil belajar peserta didik dapat meningkat. Penggunaan media pembelajaran ini dapat membantu siswa dalam memahami materi atau konsep yang terasa sulit sehingga menjadi lebih jelas dan lebih mudah dipahami (Boyd, 2019; Diyantari et al., 2020; Seruni et al., 2020). Dengan adanya media pembelajaran ini memungkinkan peserta didik untuk belajar mandiri sesuai dengan bakat dan kemampuan visual, auditori dan kinestetiknya (Daryanto, 2016; Saputri \& Qohar, 2020). Mata pelajaran Biologi materi Protista adalah salah satu materi biologi yang sulit dipahami. Sehingga membutuhkan media pembelajaran dalam penyampaian materinya.

Namun berdasarkan hasil wawancara yang dilakukan kepada guru kelas X SMAS diperoleh informasi bahwa saat proses pembelajaran biologi pada materi protista guru telah menggunakan media berupa power point serta video dan untuk pemantapan materi guru menggunakan LKPD yang sudah dirancang. Namun kelemahan dari media pembelajaran yang digunakan tersebut masih belum bisa menarik perhatian peserta didik dalam mempelajari materi Protista. Hal ini mengakibatkan pembelajaran masih belum maksimal dilakukan dikarenakan masih terdapat siswa yang tidak berpartisipasi aktif dalam pembelajaran Biologi. Permasalahan ini berdampak terhadap rendahnya hasil belajar siwa. Oleh karena itu, dalam pembelajaran protista dibutuhkan suatu media pembelajaran tambahan yang dapat membantu peserta didik dalam meningkatkan partisipasi aktif, pemahaman konsep, dan membuat pembelajaran menjadi menyenangkan, sehingga dapat menaikkan hasil belajar peserta didik (Andriyani et al., 2016; Aspini, 2020). Solusi yang dapat dilakukan adalah dengan pengembangan media pembelajaran berbentuk kartu dengan metode permainan uno.

Media pembelajaran yang diterapkan dengan menggunakan metode permainan. sesuai dengan karakteristik peserta didik usia 7-18 tahun yang cenderung menyukai permainan dalam proses pembelajaran sehingga bisa melibatkan partisipasi aktif peserta didik selama pembelajaran berlangsung (Imran \& Suryani, 2018; Pradilasari et al., 2019; Saputra et al., 2021). Media pembelajaran yang tepat salah satunya adalah media kartu. Penggunaan media kartu dalam pembelajaran memiliki beberapa kelebihan, diantaranya: mudah dibawa, mudah dibuat, mudah dalam penyajian, mudah disimpan, cocok digunakan untuk kelompok besar dan kecil,) dapat melibatkan semua siswa dalam penyajiannya, dapat dijadikan sebagai permainan yang menyenangkan, meningkatkan interaksi antar siswa, merangsang kemampuan berpikir siswa, dan, meningkatkan motivasi belajar siswa (Khairunnisak., 2015; Mardati et al., 2015; Puspita et al., 2016). Media pembelajaran dengan permainan kartu merupakan media pembelajaran yang sangat manarik bagi siswa dan mudah dipahami sehingga mudah untuk dijadikan media pembelajaran (Ayuni et al., 2017; N. M. D. Handayani et al., 2017; Rahayuningsih, 2020). Salah satu media kartu yaitu kartu UNO. Permainan uno adalah salah satu permainan yang bisa dimainkan oleh segala usia mulai dari anak-anak hingga dewasa sehingga permainan ini sangat menarik untuk dimainkan (Artini et al., 2016; Maslina, 2020).

Permainan kartu UNO merupakan salah satu permainan yang sangat menyenangkan untuk digunakan sebagai media pembelajaran (Estiani et al., 2015; Kholida et al., 2020). Permainan sebagai media pembelajaran mempunyai kelebihan yaitu sesuatu yang menyenangkan untuk dilakukan dan dapat membuat partisipasi peserta didik aktif selama pembelajaran berlangsung serta mudah dalam menerapkan konsep (Afifah \& Hartatik, 2019; Safitri et al., 2018; Susilawati et al., 2021). Sehingga mampu membantu perkembangan koginif anak karena dengan media pembelajarn akan mampu menciptakan pembelajaran yang inovatif. Permainan kartu UNO dilakukan dengan menyamakan warna atau angka pada kartu yang digunakan (Kholida et al., 2020; R. Rahmawati et al., 2019; Y. Sari \& Solehah, 2018). Perbedaan kartu UNO dengan kartu lainnya adalah kartu UNO memiliki simbol seperti wild, reservese, draw dan stop, serta pada saat kartu yang dimiliki oleh pemain tersisa satu, maka pemain tersebut harus mengatakan "UNO". Menariknya permainan kartu UNO ini terlihat sederhana, tetapi pemain harus mempunyai taktik dan strategi untuk mencapai kemenangan, sehingga permainan ini akan meningkatkan minat siswa serta daya juang siswa untuk bisa menjadi yang terbaik. Melalui permainan kartu UNO akan 
menimbulkan suasana belajar yang menyenangkan dan antara siswa akan saling bertukar pikiran sehingga materi yang disampaikan oleh guru dapat diterima dan dipahami oleh semua siswa.

Temuan penelitian sebelumnya menunjukkan bahwa media kartu UNO efektif untuk meningkatkan motivasi belajar anak untuk belajar karena permainan kartu UNO mengajak anak untuk melaksanakan proses pembelajaran sambil bermain (R. Rahmawati et al., 2019). Media kembelajaran kartu UNO berpengaruh positif terhadap motivasi dan hasil belajar peserta didik (Nova et al., 2020). Penelitian sebelumnya juga menunjukkan bahwa media pembelajaran kartu UNO mencipkatan susana belajar yang menyenangkan dan efektif sehingga mampu meningkatkan hasil belajar peserta didik (R. R. Sari \& Lutfi, 2015; Y. Sari \& Solehah, 2018). Tujuan penelitian ini adalah untuk menganalisis media pembelajaran yang perlu dikembangkan pada materi protista yang sesuai dengan kebutuhan peserta didik. Hasil dari penelitian ini diharapkan dapat memberikan informasi awal mengenai bahan ajar yang perlu dikembangkan dan kesulitan yang dialami peserta didik dalam memahami materi protista. Hasil dari penelitian ini digunakan untuk mengembangkan media pembelajaran berbentuk kartu dengan metode permainan UNO pada materi protista untuk penelitian selanjutnya.

\section{METODE}

Penelitian ini merupakan penelitian deskriptif kualitatif dengan teknik survei. Sampel penelitian yaitu 30 peserta didik kelas X IPA yang dipilih secara acak pada 5 kelas yang berbeda dan satu orang guru biologi SMAS Adabiah 2 Padang yang dilakukan pada tanggal 26 oktober 2020. Teknik yang digunakan untuk mengumpulkan data yaitu observasi, wawancara, dan kuesioner. Instrumen yang digunakan dalam penelitian ini yaitu angket ketersediaan dan penggunaan sumber belajar biologi untuk guru dan peserta didik untuk mengetahui permasalahan yang dihadapi oleh guru dan peserta didik mengenai bahan ajar yang digunakan untuk materi sistem imun manusia. Pengumpulan data dilakukan dengan menyebarkan angket kepada peserta didik dan guru biologi melalui google formulir. Teknik analisis data yang digunakan adalah teknik analisis data statistik deskriptif kuantitatif.

\section{HASIL DAN PEMBAHASAN}

Hasil

Berdasarkan hasil observasi di SMAS Adabiah 2 Padang diperoleh data yaitu pertama, Peserta didik kesulitan memahami materi pembelajaran biologi di karenakan bersifat hafalan dan materi yang terlalu banyak. Kedua, Peserta didik kesulitan memahami materi protista. Ketiga, Peserta didik sulit dalam mengklasifikasikan. Keempat, Kesulitan yang dialami peserta didik dikarenakan banyaknya istilah yang membingungkan dan materi bersifat hafalan. Kelima, Peserta didik membutuhkan media pembelajaran lain untuk menunjang pemahaman tentang materi protista. Pada materi protista beberapa kesulitan yang dihadapi oleh siswa yaitu Materi terlalu banyak dan panjang (36.7\%), Sulit dalam memahami materi (26.7\%), Sulit dalam mengklasifikasikan (23.3\%), Materi bersifat abstrak (16.7\%) dan Banyak Istilahistilah yang membingungkan (96.7\%). Hasil analisis kriteria media yang baik bagi siswa disajikan pada Tabel 1.

Tabel 1. Kriteria Media Pembelajaran Yang Menarik Bagi Peserta Didik

\begin{tabular}{ccc}
\hline No & Kriteria sumber belajar & Jumlah (\%) \\
\hline 1 & Bacaan yang disertai gambar & $46.7 \%$ \\
2 & Menggunakan metode permainan & $30.3 \%$ \\
3 & Materi yang disampaikan lengkap, singkat, padat, dan jelas & $11.3 \%$ \\
4 & Menggunakan bahasa yang mudah dipahami & $4.6 \%$ \\
5 & Dipraktekkan & $3.8 \%$ \\
6 & Ditayangkan video & $3.3 \%$ \\
\hline
\end{tabular}

Berdasarkan observasi yang peneliti lakukan pada peserta didik dan guru biologi di SMAS Adabiah 2 Padang didapatkan data bahwa peserta didik sulit memahami materi pembelajaran biologi yang disediakan sekolah, kesulitan utama dikarenakan banyaknya istilah-istilah rumit dalam media pembelajaran yang disediakan sekolah, materi yang terlalu banyak dan bersifat hafalan. Media pembelajaran yang biasa digunakan oleh peserta didik selama ini berupa modul, LKS, buku paket, LKPD, geschool, dan ditayangkan video. Peserta didik cenderung belajar materi biologi secara visual. Protista merupakan salah satu materi yang dipelajari peserta didik kelas X IPA. Menurut Bapak Azwir selaku guru biologi di SMAS Adabiah 2 Padang bahwa materi pembelajaran biologi kelas X IPA yang sulit salah satunya adalah materi protista. 
Pada saat pembelajaran materi protista, media pembelajaran yang digunakan belum maksimal membuat siswa lebih tertarik dalam pembelajaran sehingga banyak siswa yang tidak berpartisipasi aktif dan malu bertanya saat pembelajaran materi protista. Berdasarkan angket yang dibagikan kepada peserta didik dan guru biologi diperoleh data bahwa peserta didik membutuhkan media pembelajaran tambahan tentang materi protista yang bisa membuat siswa berpartisipasi aktif pada saat pembelajaran dan dapat dipahami secara mandiri. Sebanyak 83,3\% peserta didik menginginkan media pembelajaran menggunakan metode permainan yaitu media pembelajaran berbentuk kartu dengan menggunakan metode permainan UNO. Kriteria media pembelajaran yang menarik menurut peserta didik (tabel 3), yaitu media pembelajaran berbentuk kartu dengan metode permainan UNO dapat menjadi solusi permasalahan yang dihadapi oleh guru dan peserta didik.

\section{Pembahasan}

Keberhasilan pembelajaran dipengaruhi oleh kesiapan guru dalam mengajar. Pembelajaran yang menarik dan inovatif berpengaruh positif terhadap peserta didik (Awalia et al., 2019; Awaludin et al., 2020). Dalam proses pembelajaran diharapkan guru dapat menggunakan strategi dan metode pembelajaran yang tepat (Nugraheni et al., 2021; Russo et al., 2021; Schildkamp et al., 2020). Selain itu guru dapat menggunakan media pembelajaran untuk membantu siswa dalam memahami materi (Jundu et al., 2019; Suprianingsih, Ni Wayan S \& Wulandari, 2020). Media pembelajaran sebagai alat atau perantara penyampaian informasi pembelajaran yang efektif untuk mencapai tujuan pembelajaran. Media pembelajaran adalah komponen penting dalam proses pembelajaran yang perlu dipersiapkan dengan sebaik mungkin (Arfinanti, 2018; Buchori et al., 2017; Ferdiansyah et al., 2020). Dengan mengemas pembelajaran menggunakan media pembelajaran, maka perhatian siswa terhadap materi yang disampaikan akan meningkat (Ahmadi, Farid, 2017; Sadikin \& Hakim, 2019). Pembelajaran yang menarik dengan bantuan media pembelajaran akan menumbuhkan minat dan rasa senang siswa dalam belajar, sehingga mereka lebih mudah dalam memahami materi yang diberikan. Salah satu media yang dapat digunakan yaitu media pembelajaran permainan kartu UNO.

Pada dasarnya siswa menyukai sebuah permainan. Sehingga dengan memanfaatkan media pembelajarn permainan kartu UNO siswa dapat belajar sambil bermain (Kholida et al., 2020; Y. Sari \& Solehah, 2018). Media permainan kartu dapat menambah kualitas belajar siswa (Aspini, 2020; Herawati, 2017; Mahardika et al., 2013; Perdina et al., 2019). Media pembelajaran berbentuk kartu UNO yang akan dikembangkan ini dimainkan oleh 4-5 orang peserta didik dan 1 juri dari peserta didik. Cara bermainnya hampir sama dengan bermain kartu UNO pada umumnya, namun pada kartu UNO yang akan di kembangkan ini ditambahkan kartu master (topik pembelajaran), kartu materi, serta kartu soal dan jawaban. Pada setiap kartu materi terdapat penjalasan materi yang diharapkan siswa dapat memahami konsep materi sambil bermain. Sedangkan kartu soal bertujuan untuk mengetahui seberapa jauh pemahaman siswa (Aspini, 2020; Havisa et al., 2021; R. Rahmawati et al., 2019). Dalam permainan ini juga terdapat kartu simbol yang dapat digunakan sebagai strategi bagi peserta didik dalam bermain. Pada permainan kartu UNO ini nantinya kemenangan akan ditentukan dengan melihat skor paling tinggi yang di dapatkan oleh pemain dari menjawab soal. Pemberian skor ini digunakan agar peserta didik dapat berperan aktif selama permainan.

Kelebihan media pembelajaran berbentuk kartu ini berisikan materi yang singkat dan jelas, serta terdapat gambar pada beberapa kartu tertentu. Pada kartu ini juga berisikan soal dan jawaban tentang materi protista yang berguna untuk mengetahui pemahaman siswa pada materi tersebut. Terdapat kartu simbol berupa Block, Reserve, $+4,+2$, dan aturan permainan yang dapat digunakan untuk membantu peserta didik dalam melakukan permainan nantinya. Media permainan ini sangat digemari oleh peserta didik dikarenakan media permainan dianggap sebagai hiburan dan bentuknya menarik karena memiliki variasi gambar. Hasil penelitian sebelumnya juga menunjukkan media permainan berupa kartu UNO merupakan media kartu yang mengutamakan persamaan warna dan angka, dimana kartu UNO yang tersedia memiliki tujuan sebagai pendukung dalam pembelajaran, sehingga pembelajaran dapat berlangsung secara efektif dan efisien (Estiani et al., 2015; Nova et al., 2020). Penggunaan media pembelajaran yang inovatif dan menarik bagi siswa sangat berpengaruh terhadap keberhasilan pembelajaran (Faizah et al., 2021; Fartina et al., 2019; Handhika, 2012). Penelitian sebelumnya juga menunjukkan bahwa media pembelajaran kartu UNO dapat meningkatkan motivasi dan hasil belajar siswa (Kholida et al., 2020; Rahmawati et al., 2019; Sari \& Lutfi, 2015). Implikasi penelitian ini, diharapkan guru dapat menggunakan media ini untuk menciptakan suasana belajar baru yang menyenangkan sehingga dapat memudahkan siswa dalam memahami materi pembelajaran dan akan berpengaruh pada hasil belajar siswa yang meningkat. 


\section{SIMPULAN}

Media pembelajaran yang ada belum maksimal membuat peserta didik lebih tertarik dalam pembelajaran sehingga banyak siswa yang tidak berpartisipasi aktif dan malu bertanya saat pembelajaran materi protista. Pada pembelajaran protista terdapat banyak materi yang disajikan, sehingga peserta didik membutuhkan media pembelajaran tambahan untuk menunjang pemahaman materi dan membuat siswa berpartisipasi aktif dikelas. Media pembelajaran yang akan dikembangkan pada materi protista untuk peserta didik kelas X IPA SMA adalah media pembelajaran berbentuk kartu dengan metode permainan UNO, karena sesuai dengan kriteria peserta didik. Kriteria media pembelajaran yang dibutuhkan oleh peserta didik yaitu materi yang disampaikan lengkap, singkat, padat dan disertai gambar dan menggunakan metode permainan. Pengembangan media pembelajaran berbentuk kartu dengan metode permainan UNO dapat menjadi solusi dari permasalahan yang dihadapi oleh guru dan peserta didik khusunya pada materi protista.

\section{DAFTAR RUJUKAN}

Afifah, N., \& Hartatik, S. (2019). Pengaruh Media Permainan Ular Tangga terhadap Motivasi Belajar pada Pelajaran Matematika Kelas II SD Kemala Bhayangkari 1 Surabaya. MUST: Journal of Mathematics Education, Science and Technology, 4(2). https://doi.org/10.30651/must.v4i2.3035.

Ahmadi, Farid, D. (2017). Dasar, Pengembangan Media Edukasi "Multimedia Indonesian Culture" (Mic) Sebagai Penguatan Pendidikan Karakter Siswa Sekolah. Jurnal Penelitian Pendidikan, 34(2), 127136. https://doi.org/10.15294/jpp.v34i2.12368.

Amini, N., \& Suyadi, S. (2020). Media Kartu Kata Bergambar Dalam Meningkatkan Kemampuan Kosakata Anak Usia Dini. PAUDIA : Jurnal Penelitian Dalam Bidang Pendidikan Anak Usia Dini, 9(2), 119129. https://doi.org/10.26877/paudia.v9i2.6702.

Andriyani, K. P., Wisanti, \& Isnawati. (2016). Pengembangan Monopoli Protista Sebagai Media Permainan Edukatif Untuk Siswa Kelas X. BioEdu: Berkala Ilmiah Pendidikan Biologi, 5(3), 460-466.

Arfinanti, N. (2018). Pengembangan Media Pembelajaran Matakuliah Metode Numerik dengan Implementasi Scilab Berbantuan Software Latex. Al-Khwarizmi: Jurnal Pendidikan Matematika Dan Ilmu Pengetahuan Alam, 6(2), 121-138. https://doi.org/10.24256/jpmipa.v6i2.370.

Artini, N. P. W. D., Suadnyana, I. N., \& Wiarta, I. W. (2016). Penerapan Metode Bermain Berbentuk Media Kartu Angka Bergambar Untuk Meningkatkan Kemampuan Kognitif PAUD Kusuma 2. E-Journal Pendidikan Anak Usia Dini Universitas Pendidikan Ganesha, 4(1). https://doi.org/10.23887/paud.v4i1.7532.

Aspini. (2020). Implementasi Pembelajaran PBL Berbantuan Media Kartu Soal Untuk Meningkatkan Kemampuan HOTS Pada Siswa Kelas VI SD. Jurnal Edutech Undiksha, 8(1), 72-79. https://doi.org/10.23887/jeu.v8i1.27087.

Awalia, I., Pamungkas, A. S., \& Alamsyah, T. P. (2019). Pengembangan Media Pembelajaran Animasi Powtoon pada Mata Pelajaran Matematika di Kelas IV SD. Jurnal Matematika Kreatif-Inovatif, 10(1). https://doi.org/10.15294/kreano.v10i1.18534.

Awaludin, Wibawa, \& Winarsih. (2020). Integral Calculus Learning Using Problem Based Learning Model Assisted by Hypermedia-Based E-Book. Jurnal Pendidikan Indonesia, 9(2). https://doi.org/10.23887/jpi-undiksha.v9i2.23106.

Ayuni, I. A. S., Kusmariyatni, N., \& Japa, I. G. N. (2017). Pengaruh Model Pembelajaran Talking Stick Berbantuan Media Question Box Terhadap Hasil Belajar IPA Kelas V. Journal of Education Technology, 3(1). https://doi.org/10.23887/jet.v1i3.12503.

Boyd, L. (2019). Using Technology-Enabled Learning Networks to Drive Module Improvements in the UK OpenUniversity. Journal of Interactive Media in Education, 2019(1), 1-7. https://doi.org/10.5334/jime.529.

Buchori, Rahmawati, S., \& Wardani, S. (2017). The Development of A Learning Media for Visualizing the Pancasila Values Based on Information and Communication Technology. Jurnal Cakrawala Pendidikan, 36(3), 502-521. https://doi.org/10.21831/cp.v36i3.12748.

Daryanto. (2016). Media Pembelajaran. Gava Media.

Diyantari, I. A. K. D., Wiyasa, N., \& Manuaba, S. (2020). Model Snowball Throwing Berbantuan Media Pop Up Book Berpengaruh Terhadap Kompetensi Pengetahuan Ipa. Jurnal Ilmiah Pendidikan Profesi Guru, 3(1), 9-21. https://doi.org/10.23887/jippg.v3i1.26973.

Estiani, W., Widiyatmoko, A., \& Sarwi. (2015). Pengembangan Media Permainan Kartu Uno Untuk Meningkatkan Pemahaman Konsep Dan Karakter Siswa Kelas VIITema Optik. Unnes Science Education Journal, 4(1), 711-719. https://doi.org/10.15294/usej.v4i1.4974.

Faizah, U., Ambarwati, R., \& Rahayu, D. A. (2021). From offline to online learning: Various efforts to secure 
the learning process during covid-19 outbreaks. Journal of Physics: Conference Series, 1747(1). https://doi.org/10.1088/1742-6596/1747/1/012002.

Fartina, Hizbi, T., \& Syahidi, K. (2019). Development of Interactive Physics Learning Media Macromedia Flash 8 Based on Straight Motion Material. Journal of Physics: Conference Series, 1539(1). https://doi.org/10.1088/1742-6596/1539/1/012023.

Febriana. (2017). Efektivitas Model Pembelajaran Berbasis Kompetensi Dengan Pendekatan Dunia Kerja Pada Program D3 Tata Boga. Cakrawala Pendidikan, 36(1), 148-155. https://doi.org/10.21831/cp.v36i1.8891.

Ferdiansyah, F., Ambiyar, A., Zagoto, M. M., \& Putra, I. E. D. (2020). Pemanfaatan Media Pembelajaran Berbasis E Learning dalam Meningkatkan Hasil Belajar pada Matakuliah Media Pembelajaran Musik. KOMPOSISI: Jurnal Pendidikan, Bahasa Dan Seni, 21(1), 63-72. https://doi.org/10.24036/komposisi.v21i1.42098.

Handayani, H., Yetri, \& Putra, F. G. (2018). Pengembangan Media Pembelajaran Berbasis Macromedia Flash. JURNAL TATSQIF: Jurnal Pemikiran Dan Penelitian Pendidikan, 16(2), 186-203. https://doi.org/10.20414/jtq.v16i2.160.

Handayani, N. M. D., Ganing, N. N., \& Suniasih, N. W. (2017). Model Pembelajaran Picture and Picture Berbantuan Media Audio-Visual Terhadap Pengetahuan IPA. Journal of Education Technology, 1(3), 176. https://doi.org/10.23887/jet.v1i3.12502.

Handhika, J. (2012). Efektivitas media pembelajaran im3 ditinjau dari motivasi belajar. Jurnal Pendidikan IPA Indonesia, 1(2), 109-114. https://doi.org/10.15294/jpii.v1i2.2127.

Havisa, S., Solehun, S., \& Putra, T. Y. (2021). Pengaruh Metode Suku Kata Mengunakan Media Kartu Huruf terhadap Kemampuan Membaca Permulaan Siswa Kelas I SD Muhammadiyah Majaran Kabupaten Sorong. Jurnal Papeda: Jurnal Publikasi Pendidikan Dasar, 3(1), 23-31. https://doi.org/10.36232/jurnalpendidikandasar.v3i1.765.

Herawati, E. (2017). Upaya Meningkatkan Motivasi Dan Hasil Belajar Siswa Menggunakan Media Pembelajaran Kartu Domino Matematika Pada Materi Pangkat Tak Sebenarnya Dan Bentuk Akar Kelas Ix Smp Negeri Unggulan Sindang Kabupaten Indramayu. JNPM (Jurnal Nasional Pendidikan Matematika), 1(1), 66. https://doi.org/10.33603/jnpm.v1i1.254.

Imran, R. F., \& Suryani, N. A. (2018). Preoperational Development of Eearly Childhood with Insectarium Media. Jurnal Obsesi: Jurnal Pendidikan Anak Usia Dini, 2(2), 267. https://doi.org/10.31004/obsesi.v2i2.88.

Jundu, R., Jehadus, E., Nendi, F., Kurniawan, Y., \& Men, F. E. (2019). Optimalisasi Media Pembelajaran Interaktif dalam Meningkatkan Kemampuan Matematis Anak di Desa Popo Kabupaten Manggarai. E-Dimas: Jurnal Pengabdian Kepada Masyarakat, 10(2), 221. https://doi.org/10.26877/edimas.v10i2.3353.

Karo, I. R., \& Rohani. (2018). Manfaat Media Dalam Pembelajaran. Jurnal Pendidikan Dan Matematika, 7(1), 91-96. https://doi.org/10.30821/axiom.v7i1.1778.

Khairunnisak. (2015). Penggunaan Media Kartu Sebagai Strategi Dalam Pembelajaran Membaca Permulaan: Studi Kasus di Madrasah Ibtidaiyah Negeri Rukoh Banda Aceh. Jurnal Pencerahan, 9(2), 66-82. https://doi.org/10.13170/jp.9.2.2877.

Khaulani, F., Noviana, E., \& Witri, G. (2019). Penerapan Metode Brainstorming Dengan Bantuan Media Gambar Grafis Untuk Meningkatkan Hasil Belajar Pkn Siswa Kelas V SD Negeri 009 Pulau Kecamatan Bangkinang Kabupaten Kampar. Jurnal PAJAR (Pendidikan Dan Pengajaran), 3(1), $18-$ 25. https://doi.org/10.33578/pjr.v3i1.6305.

Kholida, A., Sutama, I. W., \& Suryadi, S. (2020). Pengembangan Alat Permainan Kartu U-Kids (Uno Kids) Untuk Menstimulasi Kecerdasan Logis-Matematis Anak Usia 5-6 Tahun. Cakrawala Dini: Jurnal Pendidikan Anak Usia Dini, 11(2), 76-87. https://doi.org/10.17509/cd.v11i2.24854.

Liu, S., Keeley, J. W., Sui, Y., \& Sang, L. (2021). Impact of distributed leadership on teacher job satisfaction in China: The mediating roles of teacher autonomy and teacher collaboration. Studies in Educational Evaluation, 71. https://doi.org/10.1016/j.stueduc.2021.101099.

Liu, Y., Bellibaş, M. Ş., \& Gümüş, S. (2020). The effect of instructional leadership and distributed leadership on teacher self-efficacy and job satisfaction: Mediating roles of supportive school culture and teacher collaboration. Educational Management Administration and Leadership, 1-24. https://doi.org/10.1177/1741143220910438.

Mahardika, I. G. A., Japa, I. G. N., \& Antari, N. N. M. (2013). Penerapan Metode Reciprocal Teaching Berbantuan Kartu Angka Untuk Meningkatkan Aktivitas Dan Hasil Belajar Matematika Siswa Kelas Vi Sdn 4 Penyaringan. MIMBAR PGSD Undiksha, 1(1). https://doi.org/10.23887/jjpgsd.v1i1.1400.

Mardati, Asih, \& Wangit. (2015). Pengembangan Media Permainan Kartu Gambar Dengan Teknik Make A 
Match Untuk Kelas 1 SD. Jurnal Prima Edukasia, 3(2), 120- 132. https://doi.org/10.21831/jpe.v3i2.6532.

Mardliyah, S., Yulianingsih, W., \& Putri, L. S. R. (2021). Sekolah Keluarga: Menciptakan Lingkungan Sosial untuk Membangun Empati dan Kreativitas Anak Usia Dini. Jurnal Obsesi : Jurnal Pendidikan Anak Usia Dini, 5(1). https://doi.org/10.31004/obsesi.v5i1.665.

Maslina, A. S. A. A. (2020). Pengembangan Bahan Ajar Ipa Dengan Media Audio Visual Pada Tema Selamatkan Makhluk Hidup Di Pendidikan Dasar. In Jurnal JPSD (Jurnal Pendidikan Sekolah Dasar) (Vol. 7, Issue 1). https://doi.org/10.12928/jpsd.v7i1.14467.

Nisa, K., \& Sujarwo, S. (2020). Efektivitas Komunikasi Guru terhadap Motivasi Belajar Anak Usia Dini. Jurnal Obsesi : Jurnal Pendidikan Anak Usia Dini, 5(1), 229. https://doi.org/10.31004/obsesi.v5i1.534.

Nova, F., Suprapto, P. K., \& Hernawati, D. (2020). Implementasi Kartu Uno dan Pengaruhnya terhadap Motivasi Dan Hasil Belajar Peserta Didik. Jurnal Bioterdidik: Wahana Ekspresi Ilmiah, 8(3), 84-90. https://doi.org/10.23960/jbt.v8.i3.10.

Nugraheni, N., Waluya, S. B., \& Walid, W. (2021). HOTS study primary teacher education UNNES students based on self-regulated learning. Jurnal Prima Edukasia, 9(1), 127-134. https://doi.org/10.21831/jpe.v9i1.36359.

Perdina, S., Safrina, R., \& Sumadi, T. (2019). Peningkatan Kemampuan Sosial melalui Bermain Kartu Estafet pada Anak Usia Dini. Jurnal Obsesi: Jurnal Pendidikan Anak Usia Dini, 3(2). https://doi.org/10.31004/obsesi.v3i2.222.

Pradilasari, L., Gani, A., \& Khaldun, I. (2019). Pengembangan Media Pembelajaran Berbasis Audio Visual pada Materi Koloid Untuk Meningkatkan Motivasi dan Hasil Belajar Siswa SMA. Jurnal Pendidikan Sains Indonesia, 7(1), 9-15. https://doi.org/10.24815/jpsi.v7i1.13293.

Puspita, P. M., Wirya, N., \& Antara, A. (2016). Penerapan Pendekatan Saintifik Berbantuan Media Kartu Gambar Untuk Meningkatkan Kemampuan Berbicara Di Tk Catur Paramita. Jurnal Pendidikan Anak Usia Dini Undiksha, 4(2). https://doi.org/10.23887/paud.v4i2.7809.

Rahayuningsih, S. (2020). Animation media of animal husbandry thematic science learning to stimulate scientific attitude in early childhood. International Journal of Scientific and Technology Research. https://doi.org/10.23887/jet.v3i1.17959 Article Metrics.

Rahmawati, A. (2018). Identifikasi Masalah yang Dihadapi Guru dalam Penerapan Kurikulum 2013. Indonesian Journal of Primary Education, 2(1), 114-123. https://doi.org/10.17509/ijpe.v2i1.14227.

Rahmawati, R., Muttaqin, M., \& Listiawati, M. (2019). Peran Permainan Kartu Uno Dalam Meningkatkan Keterampilan Berpikir Kritis Siswa. Jurnal Program Studi Pendidikan Biologi, 9(2), 64-75. https://doi.org/10.15575/bioeduin.v9i2.6221.

Range, B. G., Young, S., \& Hvidston, D. (2013). Teacher perceptions about observation conferences: what do teachers think about their formative supervision in one US school district? School Leadership \& Management, 33(1), 61-77. https://doi.org/10.1080/13632434.2012.724670.

Rediasih, Suwatra, \& Putri. (2019). Pengaruh Model Pembelajaran Debate Terhadap Keterampilan Berbicara Pada Mata Pelajaran Bahasa Indonesia Siswa Kelas V. Jurnal Mimbar PGSD Universitas Pendidikan Ganesha, 5(2). https://doi.org/https://ejournal.undiksha.ac.id.

Russo, J., Bobis, J., Downton, A., Livy, S., \& Sullivan, P. (2021). Primary teacher attitudes towards productive struggle in mathematics in remote learning versus classroom-based settings. Education Sciences, 11(2), 1-13. https://doi.org/10.3390/educsci11020035.

Sadikin, A., \& Hakim, N. (2019). Pengembangan Media E-Learning Interaktif dalam Menyongsong Revolusi $\begin{array}{lllll}\text { Industri } 4 . \quad J u r n a l & \text { Ilmiah } & \text { Pendidikan }\end{array}$ https://doi.org/10.22437/bio.v5i2.7590.

Safitri, R. W., Primiani, C. N., \& Hartini, H. (2018). Pengembangan Media Flashcard Tematik Berbasis Permainan Tradisional Untuk Kelas IV Sub Tema Lingkungan Tempat Tinggalku. Pendidikan Dasar Dan Pembelajaran, 8(1), 11. https://doi.org/10.25273/pe.v8i1.1332.

Saputra, N., Hikmah, N., Yustitia, V., Saputra, M., Wahab, A., \& Junaedi, J. (2021). Implementation of Online Learning Using Online Media, During the Covid 19 Pandemic. Budapest International Research and Critics Institute (BIRCI-Journal): Humanities and Social Sciences, 4(2), 1802-1808. https://doi.org/10.33258/birci.v4i2.1857.

Saputri, R. R., \& Qohar, A. (2020). Development of Comic-Based Mathematics Learning Media on Social Arithmetic Topic. Journal of Physics: Conference Series, 1657, 012082. https://doi.org/10.1088/1742-6596/1657/1/012082.

Sari, R. R., \& Lutfi, A. (2015). Kelayakan Permainan UNO Card Sebagai Media Pembelajaran Pada Materi Pokok Struktur Atom. UNESA Journal of Chemical Education, 4(2), 186-194. 
Sari, Y., \& Solehah, M. T. M. (2018). Pengaruh Penggunaan Media Permainan Kartu Uno Pada Materi Senyawa Hidrokarbon Terhadap Hasil Belajar Siswa. Vidya Karya, 33(1). https://doi.org/10.20527/jvk.v33i1.5391.

Schildkamp, K., Kleij, van der, Heitink, Kippers, W. B., \& Veldkamp, B. P. (2020). Formative assessment: A systematic review of critical teacher prerequisites for classroom practice. International Journal of Educational Research. https://doi.org/10.1016/j.ijer.2020.101602.

Seruni, R., Munawaroh, S., Kurniadewi, F., \& Nurjayadi, M. (2020). Implementation of E-module flip PDF professional to improve students' critical thinking skills through problem based learning. Journal of Physics: Conference Series, 1521(4), 1-6. https://doi.org/10.1088/1742-6596/1521/4/042085.

Suprianingsih, Ni Wayan S \& Wulandari, I. G. (2020). Model Problem Posing Berbantuan Media Question Box Berpengaruh Terhadap Kompetensi Pengetahuan Matematika Siswa SD. Jurnal Mimbar Ilmu, 25(3), 308-318. https://doi.org/10.23887/mi.v25i3.25472.

Susilawati, E., Puspitasari, D., Kusumadewi, F., \& Nuryanih, L. (2021). Modifikasi Permainan Tradisional Congklak Terhadap Kemampuan Berhitung Untuk Meningkatkan Perkembangan Kognitif Pada Anak Usia Dini Tahun 2020. Jurnal Mutiara Ners, 4(1), 24-30. https://doi.org/10.51544/jmn.v4i1.1297.

Ulfah, D. M., \& Soenarto, S. (2017). Pengaruh penggunaan media video dan gambar terhadap keterampilan menulis kelas V. Jurnal Prima Edukasia, 5(1), 22-34. https://doi.org/10.21831/jpe.v5i1.7693.

Wahyono, P., Husamah, H., \& Budi, A. S. (2020). Guru profesional di masa pandemi COVID-19: Review implementasi, tantangan, dan solusi pembelajaran daring. Jurnal Pendidikan Profesi Guru, 1(1), 51-65. https://doi.org/10.22219/jppg.v1i1.12462. 